\title{
Study of the Features of Adaptation of Intellectual Capital in Regions with Weak Economy to the Conditions of "Big Challenges"
}

\author{
Suvorova A.P. \\ Volga State Technological University, \\ Yoshkar-Ola, Russia, \\ saprof@mail.ru \\ Repina O.M. \\ Volga State Technological University, \\ Yoshkar-Ola, Russia, \\ n_stash@mail.r
}

\author{
Sudakova N.Yu. \\ Volga State Technological University, \\ Yoshkar-Ola, Russia, \\ repinaom@yandex.ru \\ Rudenko S.A \\ Volga State Technological University, \\ Yoshkar-Ola, Russia, \\ rudenkosval@mail.ru
}

\begin{abstract}
In the modern economy, the model of state management of territorial development is changing. It is being built taking into account the complex external environment and the existing "big challenges". The authors studied foreign experience and highlighted approaches to establishing significant factors of economic development of territories. It is noted that the degree of adaptation of the region's intellectual capital is determined by the qualitative transformation of intellectual potential into intellectual capital, which is reflected in the results of using capital through intellectual activity. As indicators of the level of intellectual potential, intellectual capital and intellectual activity of the region, it was proposed to use indicators for monitoring the implementation of the Strategy of Scientific and Technological Development of the Russian Federation. The author's approach to the classification of weak regions of the Russian Federation by the level of scientific and technological development is presented, an assessment of the level of adaptation of the intellectual capital of selected regions with a weak economy to the conditions of "big challenges" is given, the practice of effective decisions of regional authorities to implement the strategy of the scientific and technological development of the Russian Federation is considered, the reasons for successful adaptation intellectual capital of weak regions to the conditions of "big challenges".
\end{abstract}

Keywords-“big challenges", intellectual capital, intellectual potential, intellectual activity

\section{INTRODUCTION}

The development of the world economy at the present stage is determined and will be determined in the future not so much by the availability of resources on the territory of the countries, but by the efficiency of the system of state support for science, technology and innovation, changes in the mechanisms and models of management. In the context of such a strategic orientation of the economy, science is positioned not as an independent sector, but is increasingly focused on solving the problems of social development. These problems facing society are built into a system of "big challenges". Territorial development management should organically transform in the face of these changes, adapt to them. Such adaptation makes it possible to determine a list of key directions for the development of each territory, ensuring the leveling of threats posed by "big challenges", on the one hand, and effective use of opportunities, on the other.

The "big challenges" model becomes the foundation for the formation of a promising scientific policy and an incentive for the development of state support mechanisms aimed at the rapid transformation of scientific ideas into technologies, and technologies into products that are in demand on the national and world markets, which are necessary to significantly improve the quality of life of the population.

Over the past twenty years, total expenditures on Russian science have increased 13 times (from 76.7 billion rubles to 1028.2 billion rubles) and account for only $1.1 \%$ of the country's GDP. According to the experts of the Accounts Chamber of the Russian Federation, the funding of Russian scientific research, as before, lags behind the level of developed countries. At the same time, in terms of the volume of relative expenditures on science, Russia is in 34th place in the world: the number of patent applications in Russia is 16 times less than in the United States, and 38 times less than in China. The current situation is largely due to the effect of a low base, when the development of science for a long period of time was monooriented, aimed at strengthening the competitive status of the country's defense-industrial complex and the aerospace industry.

The "big challenges" that are relevant for the world economy as a whole are significant for Russia as well. At the 
same time, they are supplemented by national problems related to the peculiarities of logistics systems, transport, industrial and economic connectivity of regions, distribution of raw materials due to the influence of the spatial factor. "Big Challenges" became a trigger for the implementation of the STI approach in managing sustainable territorial development based on the use of science, technology and innovation (STI). This approach was presented in the report of the UN Secretary General in 2013 "Millennium Development Goals" [1].

Russia's response to the "big challenges" was the "Strategy of the Scientific and Technological Federation of the Russian Federation", approved by the decree of the President of the Russian Federation dated 01.12.2016 No. 642 [2]. One of the results of the implementation of this strategy should be the effective development and use of space, including by overcoming imbalances in the socio-economic development of the country's territory. The main approach to strategy development is that "big challenges" require a response from the state, and the scale and complexity of these problems does not allow them to be solved, eliminated, or implemented solely by increasing resources, i.e. due to extensive factors.

Thus, we believe that in order to overcome the "big challenges" changes are needed within the Russian economic system due to qualitative intensive factors. Intellectual capital is a key factor in scientific and technological development, which is the basis of the STI model.

\section{RESULTS AND DISCUSSION}

Establishing the relationship between the processes of adaptation of the intellectual capital of territories and the development of the situation when the "big challenges" are embodied in a strategic complex of threats and opportunities for territorial development, it is necessary to rely on a set of approaches that have developed in economic science to determine the significant factors of innovative development of territorial socio-economic systems.

Economic concepts that emerged and developed until the second half of the 20th century recognized the priority role of factors of production in regional economic development. The emergence of the theory of innovation in the first half of the 20th century changed the alignment of accents in the structure of factors of economic development. P. Drucker, T. Hegerstrand, G. Mensch, J. Schumpeter, A. Kleinknecht and other researchers have identified the role of innovation as a leading factor in territorial development.

Alternative theories of innovations of the twentieth century interpret innovations as drivers of territorial development outside of purely economic processes. K. Freeman translated the ideas of innovative development through the prism of employment and other social aspects. He drew attention to the fact that employment is not only a consequence of fluctuations in various spheres of economic activity, but also itself becomes a trigger, a switch of economic activity in the territory.

The theory of the triple helix asserted that in the chain "universities - business - power", universities play the prevailing role in the knowledge-based. In this coordinate system, favorable conditions are created for the development of an innovative environment in which cross-formations are formed: firms created on the basis of universities; strategic alliances between enterprises of different industries and levels of technological development; government research laboratories and technology platforms. This approach is very close to the approach of the founder of the theory of innovative ecosystems R. Ayres, who draws the attention of researchers to the complex nature of the process of economic development and the many environmental factors that influence it.

An intellectual response to the escalating global economic and political challenges was the development of a new scientific concept called the "theory of sustainable development". The approach is based on the idea that due to the limited growth limits of the economy and industry of the territories, the reduction in the amount of available natural resources, a new concept of sustainable development of the world is needed, based on the balance of the economy and the environment, on the change in the value orientations of society and society.

Taking into account the influence of the human factor on the economic development of the territory became possible thanks to the creation of the theory of endogenous economic growth and the concept of the formation of human capital.

Thus, K. Arrow proposed one of the first models of endogenous economic growth, in which the learning-by-doing process plays an important role. The influence of human capital on the dynamics of economic systems was described in his approach by R. Lucas. Representatives of the neoinstitutional economic concept also tried to substantiate the importance of human capital and models of human behavior as a factor in the development of the socio-economic system. Representatives of the futurological concept went even further in their conclusions, confirming as a decisive factor in development the formation of an innovative type of person who has an updated system of value orientations corresponding to the economy of a postindustrial society, capable of making changes in the world around him.

It is interesting to consider the selected approaches from the point of view of the conditions for the development of territories. The problem of establishing the role of human capital in this process, which makes it possible to ensure the adaptability of the socio-economic system of the territory to the ongoing changes, remains debatable [3-6].

Table I presents a comparative analysis of approaches to understanding the significant factors in the development of territorial socio-economic systems.

A review of scientific literature made it possible to conclude that the attempts undertaken to comprehensively substantiate the system of factors for the innovative development of territorial socio-economic systems are not sufficient and exhaustive. They do not allow for forming a mechanism for adapting the intellectual capital of the territory to the conditions of strategic changes in the environment [7].

\section{MATERIALS AND METHODS}

The main message of the Strategy of Scientific and Technological Development of the Russian Federation is the provision on increasing the efficiency of the development and use of space by overcoming the disproportions in the socioeconomic development of the country's territory. An increase in economic activity and competitiveness of Russian regions depends on the rational use of their comparative advantages, taking into account the available intellectual capital. 
TABLE I. APPROACHES TO ESTABLISHING SIGNIFICANT FACTORS OF ECONOMIC DEVELOPMENT OF TERRITORIES

\begin{tabular}{|c|c|}
\hline $\begin{array}{c}\text { Approach } \\
\text { (authors of the approach) }\end{array}$ & Summary of the Approach \\
\hline $\begin{array}{l}\text { Classical theories of regional } \\
\text { development }\end{array}$ & $\begin{array}{l}\text { The predominance of the role of } \\
\text { economic factors, primarily factors } \\
\text { of production }\end{array}$ \\
\hline $\begin{array}{l}\text { Classical theories of innovation } \\
\text { (P. Drucker, 1942; J. Schumpeter, } \\
\text { 1982, etc.) }\end{array}$ & $\begin{array}{l}\text { Innovation as a Leading Factor of } \\
\text { Economic Development }\end{array}$ \\
\hline $\begin{array}{l}\text { Social Theory of Innovation } \\
\text { (K. Freeman, 1974) }\end{array}$ & $\begin{array}{l}\text { Social and public relations that have } \\
\text { developed within territorial socio- } \\
\text { economic systems are a factor of } \\
\text { economic development }\end{array}$ \\
\hline $\begin{array}{l}\text { Triple Helix Theory (G. Itskovich, } \\
\text { L. Leidesdorff, 1995; R. Ayres, } \\
\text { 2004) }\end{array}$ & $\begin{array}{l}\text { A factor in the economic } \\
\text { development of the territory is the } \\
\text { formation of knowledge } \\
\text { infrastructure through the partial } \\
\text { combination of science, business and } \\
\text { government on the basis of mutual } \\
\text { exchange of functions }\end{array}$ \\
\hline $\begin{array}{l}\text { Sustainable Development Theory } \\
\text { (D. Medows, 1991) }\end{array}$ & $\begin{array}{l}\text { The key factor is the creation of } \\
\text { conditions for sustainable interaction } \\
\text { of innovations and three aspects of } \\
\text { the territorial environment: } \\
\text { economic, social and environmental }\end{array}$ \\
\hline $\begin{array}{l}\text { Human Capital Theories (K. Arrow, } \\
\text { 1962; R. Lucas, 2002) }\end{array}$ & $\begin{array}{l}\text { Recognition of the role of human } \\
\text { capital and the creation of conditions } \\
\text { for its reproduction in stimulating the } \\
\text { dynamics of economic systems }\end{array}$ \\
\hline 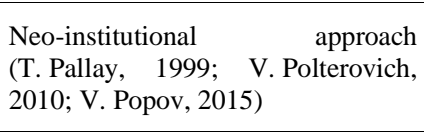 & $\begin{array}{l}\text { The importance of human capital and } \\
\text { models of human behavior as a factor } \\
\text { in the development of the socio- } \\
\text { economic system is determined }\end{array}$ \\
\hline $\begin{array}{l}\text { Futurological approach (J. Naisbitt, } \\
\text { 1992; E. Toffler, 2010) }\end{array}$ & $\begin{array}{l}\text { The decisive factor is the formation } \\
\text { of an innovative type of person } \\
\text { capable of designing and } \\
\text { implementing changes in the } \\
\text { economy and the world as a whole }\end{array}$ \\
\hline
\end{tabular}

Source: Author's analysis of literature sources [8]

The purpose of the study is to develop a methodological approach to assessing the effectiveness of the adaptation of the intellectual capital of regions with a weak economy to the conditions of "big challenges".

The subject of this study is to identify the features of the adaptation of the intellectual capital of Russian regions to the conditions of the "big challenges" stated in the Strategy of Scientific and Technological Development of the Russian Federation. Russian regions with a weak economy are of particular interest for research as an object for considering the process of transition of intellectual potential into a qualitative component - intellectual capital [9].

We believe that the degree of adaptation of the region's intellectual capital is determined by the qualitative transformation of intellectual potential into intellectual capital, which is reflected in the results of using capital through intellectual activity. The author's position is that indicators of the intellectual potential, intellectual capital and intellectual activity of the region are indicators of monitoring the implementation of the Strategy of Scientific and Technological Development of the Russian Federation, provided with a statistical base.

We have proposed a classification of the system of indicators for the implementation of the above Strategy in accordance with the process of transforming intellectual potential into the results of intellectual activity. To achieve the objectives of the study, it is necessary to identify regions with a weak economy, then group them according to the degree of scientific and technological development and, as a result, assess the level of adaptation of the intellectual capital of the selected regions.

In order to highlight regions with a weak economy, it was assumed that the performance of any socio-economic system can be assessed as the ratio of the result obtained to the invested costs. To assess the effectiveness of the scientific and technological development of the regions of the Russian Federation, investment return $(\mathrm{Q} / \mathrm{R})$ was considered as an indicator of efficiency - an indicator characterizing the value of innovative products per unit of investment, where $Q$ is innovative products, $\mathrm{R}$ is the amount of investment in innovative products. The following costs are attributed to the value of investments in innovative products: internal costs for research and development, costs for technological innovation, capital costs for research and development.

As additional indicators of the effectiveness of the scientific and technological development of the regions of the Russian Federation, the following were calculated: the period of turnover of costs for innovative products $(T / R)$ - the duration of the period required to develop a unit of consumed resource, where $\mathrm{T}$ is the duration of the period (360 days); productivity of innovative products $(\mathrm{Q} / \mathrm{T})$, which is taken as the volume of innovative products per unit period of the reporting period. Calculations were made for the entire range of regions based on the determination of the dynamics of changes in indicators by the growth (decrease) coefficient for the period from 2016 to 2018 from the moment the implementation of the Strategy for Scientific and Technological Development of the Russian Federation began. As a result, we have identified regions with a weak economy. These included all regions where at least one growth (decline) coefficient for one of the above three indicators was less than 0.75 .

At the next stage of the study, the identified regions were grouped into three groups: very weak, moderately weak and relatively weak. The criterion for assigning regions to these groups was the number of indicators of the effectiveness of scientific and technological development of the regions of the Russian Federation, for which the average growth (decline) rates are less than 0.75 . The first group included the regions in which the rate of decline of all three indicators is more than $25 \%$; in the second group - the regions in which the rate of decline of two indicators out of three is more than $25 \%$, in the third group - the regions in which the rate of decline of only one indicator is more than $25 \%$. The grouping of weak regions according to the degree of scientific and technological development is presented in Table II.

At the final stage of the study, an assessment was made of the level of adaptation of the intellectual capital of the selected regions with a weak economy to the conditions of "big challenges". For this, changes in the average growth (decrease) rate of indicators of intellectual potential (IP), intellectual capital (IC) and intellectual activity (ID) of the region were determined, calculated on the basis of indicators of the implementation of the Strategy of Scientific and Technical Development of the Russian Federation (Fig. 1).

The calculation was made based on the results of monitoring the implementation of the STD Strategy for 2015-2018 (Fig. 1$3)$. 
TABLE II GROUPING OF WeAK REGIONS BY THE DEGREE OF SCIENTIFIC AND TECHNOLOGICAL DEVELOPMENT (CALCULATIONS WERE MADE IN ACCORDANCE WITH STATIC DATA [10])

\begin{tabular}{|c|c|c|c|c|}
\hline \multirow{2}{*}{ Group } & \multirow{2}{*}{ Regions } & \multicolumn{3}{|c|}{ Average ratio } \\
\hline & & \begin{tabular}{|l|}
$\mathbf{Q} / \mathbf{R}$ \\
growth
\end{tabular} & $\begin{array}{c}\mathrm{T} / \mathrm{R} \\
\text { reduction }\end{array}$ & $\begin{array}{c}\text { growth } \\
\mathbf{Q} / \mathbf{T}\end{array}$ \\
\hline \multirow{14}{*}{ 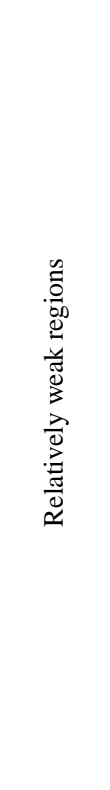 } & Amur Region & 1.234 & 0.662 & 1.004 \\
\hline & Irkutsk Region & 0.605 & 2.241 & 0.906 \\
\hline & Kurgan Region & 1.340 & 0.689 & 1.112 \\
\hline & Republic of Mordovia & 1.368 & 0.612 & 1.070 \\
\hline & Udmurt Republic & 0.732 & 1.755 & 0.970 \\
\hline & Republic of Ingushetia & 0.718 & 1.505 & 0.881 \\
\hline & Kabardino-Balkar Republic & 0.653 & 1.744 & 0.863 \\
\hline & Volgograd Region & 1.360 & 0.525 & 0.986 \\
\hline & Kaliningrad Region & 2.137 & 0.390 & 1.335 \\
\hline & Nenets Autonomous Okrug & 5.109 & 0.074 & 1.392 \\
\hline & Bryansk Region & 0.451 & 0.987 & 0.454 \\
\hline & Kostroma Region & 0.689 & 2.697 & 1.127 \\
\hline & Tver Region & 1.554 & 0.423 & 1.011 \\
\hline & Yaroslavl Region & 1.218 & 0.683 & 1.007 \\
\hline \multirow{10}{*}{ 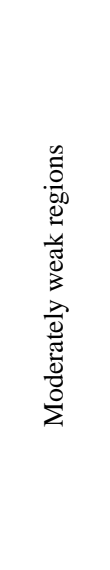 } & Moscow & 0.565 & 0.973 & 0.557 \\
\hline & Komi Republic & 0.475 & 2.721 & 0.784 \\
\hline & Vologda Region & 0.661 & 1.352 & 0.769 \\
\hline & Murmansk Region & 0.475 & 2.475 & 0.748 \\
\hline & Astrakhan Region & 0.303 & 0.529 & 0.220 \\
\hline & Rostov Region & 0.844 & 0.675 & 0.694 \\
\hline & Chechen Republic & 0 & 1.119 & 0 \\
\hline & $\begin{array}{l}\text { Yamalo-Nenets Autonomous } \\
\text { District }\end{array}$ & 0.343 & 1.654 & 0.441 \\
\hline & Republic of Sakha (Yakutia) & 0.387 & 1.882 & 0.532 \\
\hline & Zabaykalsky Krai & 0.251 & 1.298 & 0.286 \\
\hline \multirow{2}{*}{ 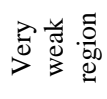 } & Kemerovo Region & 0.773 & 0.903 & 0.735 \\
\hline & Mari El Republic & 0.660 & 0.792 & 0.588 \\
\hline
\end{tabular}

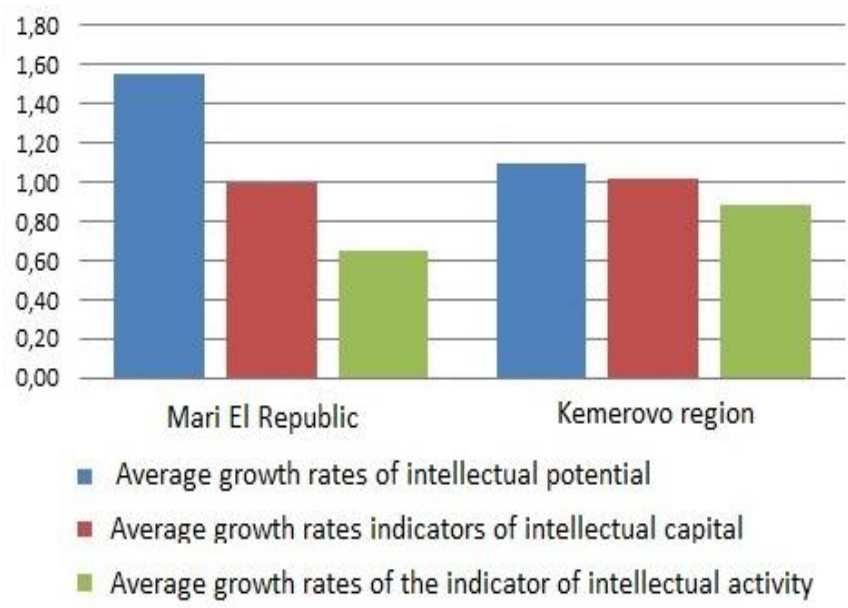

Fig. 1. Average growth rates of IP, IC and ID indicators in very weak regions

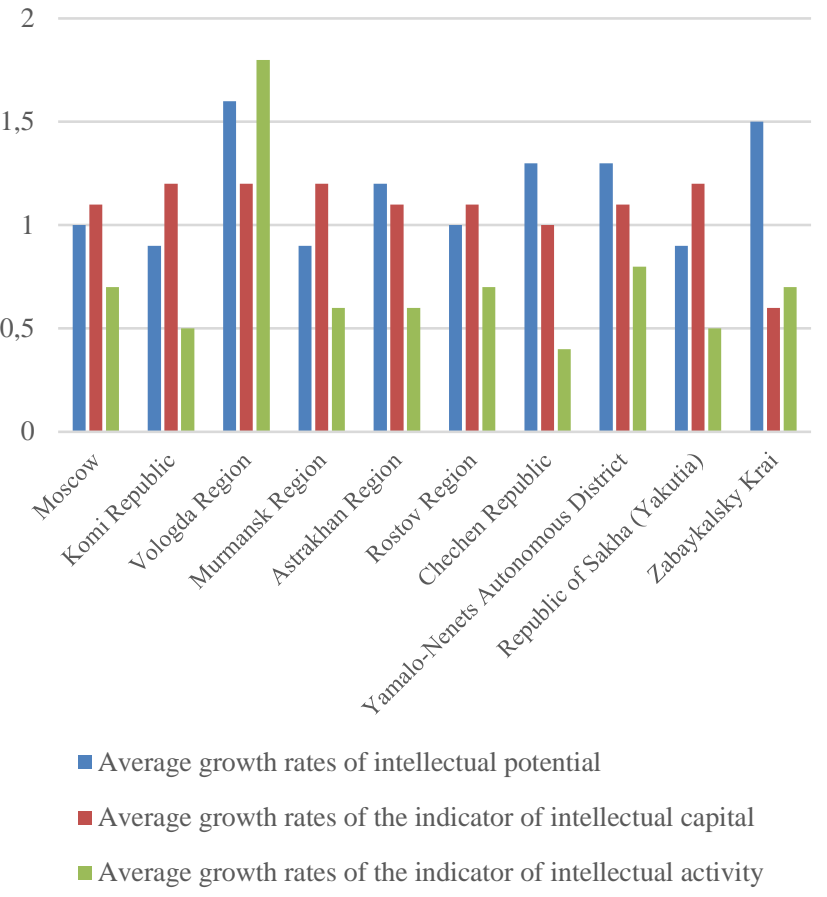

Fig. 2. Average growth rates of IP, IC and ID indicators in moderately weak regions

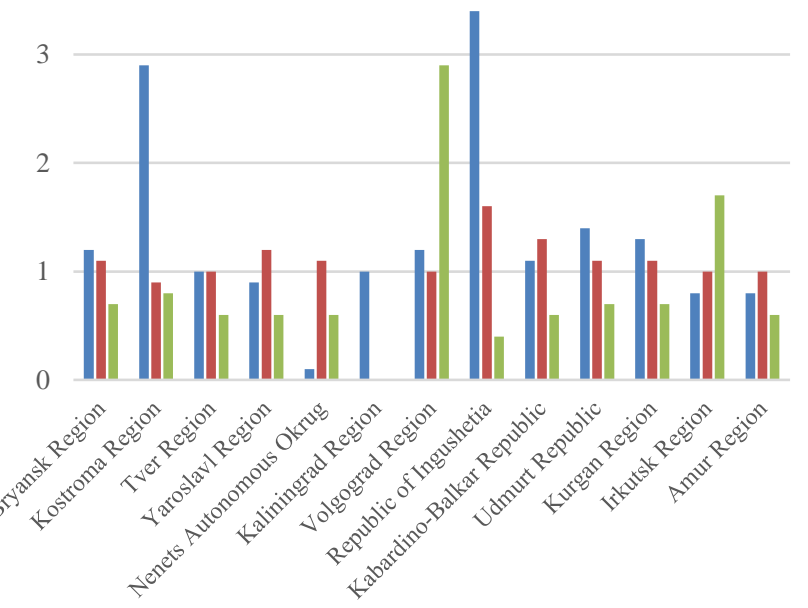

n Average growth rates of intellectual potential

- Average growth rates of the indicator of intellectual capital

Average growth rates of the indicator of intellectual activity

Fig. 3. Average growth rates of IP, IC and ID indicators of relatively weak regions

To calculate the indicators, only a part of the indicators presented in the monitoring was used.

\section{CONCLUSION}

Based on the results obtained, the following conclusions can be drawn:

- The intellectual capital of the regions belonging to the group of very weak - the Republic of Mari El and the 
Kemerovo region - have not sufficiently adapted to the conditions of "big challenges" and are at the stage of accumulating intellectual potential;

- 2. 10 regions included in group 2 - moderately weak are moving from the accumulation of intellectual potential to the process of forming the intellectual capital of the region. However, it cannot be said that they have successfully adapted to the conditions of "big challenges";

- 3. The third group of regions - relatively weak - show different results of adaptation to the conditions of "big challenges". It includes regions that successfully conduct innovative activities (Volgograd region, Republic of Ingushetia and Irkutsk region), the growth rate of the indicator of intellectual activity in them is 200-300\%, and regions (Bryansk region, Republic of Mordovia) that have poorly adapted and show low rates growth, as well as regions (Nenets Autonomous Okrug) that are at the stage of accumulating intellectual potential.

Based on the study of the effective practice of decisions of regional authorities on the implementation of the Strategy of the Scientific and Technological Development of the Russian Federation, the reasons for the successful adaptation of the intellectual capital of territories from the second and third groups of weak regions to the conditions of "big challenges" are revealed. The predominant interest was aroused by those regions that showed high growth rates of the indicator of intellectual activity.

Thus, the regional authorities of the Irkutsk region have created the necessary conditions for attracting extra-budgetary funds in order to promote large investment projects of nonnuclear production in the region. The maximum effective use of intellectual capital makes it possible to successfully develop business cooperation between state corporations and enterprises in the region within the existing industrial cluster.

In the Vologda Region, the regional authorities are actively implementing the Vologda Hectare program by bringing unused farmland into circulation, which is provided free of charge. The result of the implementation of the program should be an improvement in the organization of territories, the rational use of land and, as a result, the development of the regional economy and scientific support of agriculture at the expense of extra-budgetary funds. The tool for promoting the program is the creation of the state information system "Vologda hectare".

The Republic of Ingushetia has an extensive program of support for small and medium-sized businesses, which provides an increase in intellectual activity through the creation of professional educational institutions and the involvement of young people in entrepreneurial activity.

In the Volgograd region, mechanisms of grant support for strategic sectors of the regional economy are actively used, conditions are being created for effective interaction between science and industry. The technologies of project activity in the form of the project office "Idea Factory" allow for getting the maximum return for the regional economy from the use of developed intellectual capital.

Thus, the study revealed that Russian regions have different opportunities in terms of the formation of intellectual potential and the accumulation of intellectual capital; the socio-economic development of the territory and the standard of living of the population are characterized by disproportions; the effectiveness of innovation depends on how well the regional authorities use the available resources and the comparative advantages of the region. The solution of the strategic tasks of the development of regions with a weak economy, necessary for the conditions of "big challenges", requires coordination of efforts of the state, society, economy and business to form intellectual potential and transformation of intellectual capital into the results of intellectual activity.

\section{References}

[1] The Millennium Development Goals: Report 2013, Published by the United Nations, New York 13-26320-June 2013-500. Retrieved from: http://mdgs.un.org/unsd/mdg/Resources/Static/Products/Progress2013/R ussian2013.pdf

[2] The strategy of scientific and technological development of the Russian Federation Approved by the Decree of the President of the Russian Federation dated 01.12.2016 no. 642 [Strategiya nauchnotekhnologicheskogo razvitiya Rossijskoj Federacii Utverzhdena Ukazom Prezidenta Rossijskoj Federacii ot 01.12.2016 g. № 642]. Retrieved from: http://www.kremlin.ru/acts/bank/41449

[3] R. Arocena, "Power, Innovation Systems And Development", Innovation and Development, 2018, vol. 8:2, pp. 271-285.

[4] S. Arvanitis, F. Seliger and T. Stucki, "The Relative Importance O Human Resource Management Practices For Innovation”, Economics of Innovation and New Technology, 2016, vol. 25, pp. 769-800.

[5] R. Brown and S. Mawson, "Entrepreneurial Ecosystems And Public Policy In Action: A Critique Of The Latest Industrial Policy Blockbuster". Cambridge Journal of Regions Economy and Society 2019, vol. 12, pp. 347-368.

[6] M. Grillitsch, B. Asheim and M. Trippl, "Unrelated Knowledge Combinations: The Unexplored Potential For Regional Industrial Path Development", Cambridge Journal of Regions, Economy and Society, 2018, vol. 11, pp. 257-274.

[7] M. Barzotto, C. Corradini, F.M. Fai, S. Labory and Ph.R. Tomlinson, "Enhancing Innovative Capabilities In Lagging Regions: An ExtraRegional Collaborative Approach To RIS3", Cambridge Journal of Regions, Economy and Society 2019, vol. 12, pp. 213-232.

[8] A.P. Suvorova and N.Yu. Sudakova, Modern financial technologies-a catalyst for regional development in conditions of sustainable growth // Financial neo-futurism-100 years of management theory and practice: materials of the 9 th international scientific and practical conference. State University of Management [Covremennye finansovye tekhnologiikatalizator regional'nogo razvitiya $\mathrm{v}$ usloviyah ustojchivogo rosta // Finansovyj neofuturizm -100 let teorii i praktiki upravleniya: materialy 9-j mezhdunarodnoj nauchno-prakticheskoj konferencii. Gosudarstvennyj universitet upravleniya], Moscow, 2019. pp. 141-145.

[9] A.P. Suvorova, O.M. Repina, S.A. Rudenko, L.V. Bakulevskaya, O.A. Kirpicheva and A.V. Stepanov, Development of A Concept to Improve the Quality of Life of The Region's Population Based on A Study of The Factors of Human Capital Development in The Conditions of Innovative Systems // 35th IBIMA Conference: 1-2 April 2020, Seville, Spain. Retriewed from: https://ibima.org/accepted-paper/development-of-aconcept-to-improve-the-quality-of-life-of-the-regions-population-basedon-a-study-of-the-factors-of-human-capital-development-in-theconditions-of-innovative-systems/

[10] Statistical collection "Regions of Russia. Socio-economic indicators" [Statisticheskij sbornik "Regiony Rossii. Social'no-ekonomicheskie pokazateli"]. Retriewed from: https://rosstat.gov.ru/folder/210/document/47652 